\title{
ビルオーナーとテナントの意思決定を考慮した建築物省エネ施策の効果予測 PREDICTING THE EFFECTS OF ENERGY SAVING POLICIES IN BUILDING SECTOR IN CONSIDERATION OF BUILDING OWNERS' AND TENANTS' DECISION MAKING
}

\author{
大音裕紀*1, 赤司 泰義*2, 林 鍾 衍*3, 宮田翔平*4 \\ Yuki OTO, Yasunori AKASHI, Jongyeon LIM \\ and Shohei MIYATA
}

\begin{abstract}
To achieve the sustainable development, the government has conducted some policies about energy policy of buildings. To make the policy making better, we need to know how the policies affect the society and energy consumption. In order to predict these effects of policies, a Multi-Agent Simulation model considering office building owners and their tenants is developed. Using this model, effects of some policies are estimated, and we got important results for policy making. We also clarified that tenants' intension to energy plays an important role in energy policy. Particularly, subsidies have a synergy with tenants' intension to energy saving.
\end{abstract}

Keywords : Multi Agent Simulation, Energy policy, Office building, Future prediction, Building owner, Tenant マルチェージェントシミュレーション, 省エネ施策, オフィスビル, 将来予測, ビルオーナー, テナント

\section{1. はじめに}

\section{1 研究背景}

2015 年に採択されたパリ協定において、日本は温室効果ガス排出 量を 2013 年度比で 2030 年度までに $26 \%$ 減とすることを目標に掲 げている。そして、目標の内訳として民生業務部門では温室効果ガ ス排出量を $40 \%$ 減とすることが求められている ${ }^{11}$ 。目標達成には技 術革新と同時に、既存技術の普及を促進する施策的な支援が不可欠 であり、わが国ではこれまでも建築物省エネ法 2)や各種補助金など の手段で建築物の省エネ化を推進してきた。こういった施策の効果 を最大化するには、個々の施策や複数施策の組み合わせによる省エ ネ効果を定量的に予測することが必要である。この予測においては、 施策によって建築物に関わるビルオーナーやテナントといったステ ークホルダーの意思決定が変化し、結果として省エネ化が推進され るというプロセスを考慮することが重要である。

以上のような背景から、本研究はステークホルダーの意思決定を 考慮した省エネ施策の効果予測を行うことを目的としている。施策 効果の予測対象は、民生業務部門のうち、代表的な建築物の形態で ある事務所ビルとした。また、事務所ビルにかかわる
ステークホルダーは設計者や施工者、ディベロッパーなど多数考 えられるが、その中でも新築・改修・運用等の意思決定を直接行う ビルオーナーと、ビルの収益に直接かかわるテナントの 2 種類が最 も重要であると考え、貸オフィスビル（以下、ビル）を対象に、そ の主要な意思決定者であるビルオーナーとテナントの行動をモデル 化したシミュレーションを構築した。このシミュレーション上でい くつかの省エネ施策とそれらの組み合わせを適用した場合の一次エ ネルギー消費量を予測することで、各施策とその組み合わせの省エ ネ効果について検討している。例えば、省エネ改修の補助金がある と、ビルオーナーは改修のイニシャルコストが低減できるために省 エネ改修の実施を決定する可能性が高くなる。あるいは、テナント の省エネ意識が高いと、省エネ性能がより高いビルに入居する可能 性が高まり、そういったビルの需要が増えることが期待できる。こ ういった意思決定が長期的にはストック建築物全体の省エネ性を高 めていくことになる。

本研究のような、都市規模の消費エネルギー予測等に関連したシ ミュレーションには一般に、全体の現象を数理モデルで表し、それ を微分方程式などで解くトップダウン型のシミュレーションと、現
"1 (株)大林組（元 東京大学大学院工学系研究科建築学専攻 大学院生) 修士 (工学)

2 東京大学大学院工学系研究科建築学専攻 教授·工博

33国立江原大学校 (韓国) 建築工学科 助教授・博士 (工学) / 国立江原大学校 (韓国) 新産業開発融合学科 助教授·博士 (工学)

·4 東京大学大学院工学系研究科建築学専攻 助教・博士 (工学)
Obayashi Corporation (Former Grad. Student, Dept. of Architecture, Faculty of Engineering, The University of Tokyo), M.Eng.

Prof., Dept. of Architecture, Faculty of Engineering, The University of Tokyo, Dr.Eng.

Assist. Prof. / Ph.D., Dept. of Architectural Engineering, Kangwon National University / Assist. Prof. / Ph.D., Dept. of Integrated Energy and Infra System, Kangwon National University

Assist. Prof., Dept. of Architecture, Faculty of Engineering, The University. of Tokyo, Dr.Eng. 
象を行動要素単位でとらえて複雑系モデルで記述し、各要素の行動 の総体から大局的な事象を算出するボトムアップ型のものがある ${ }^{3)}$

トップダウン型のシミュレーションによる既往研究としては、伊 香賀らが、将来推計人口、着工床面積などの統計データに基づき、 建築関連 $\mathrm{CO}_{2}$ 排出量を 2050 年まで予測した研究がある ${ }^{4)}$ この研 究では、平均的な建築物の工事、運用におけるエネルギー消費量の シナリオ、電力の $\mathrm{CO}_{2}$ 排出原単位別によるいくつかのシナリオにつ いて $\mathrm{CO}_{2}$ 排出量を予測しているが、統計資料に基づき建築分野全体 の $\mathrm{CO}_{2}$ 排出量を予測するものであり、政策が建築物の性能に影響を 与える過程の説明はできない。また、近年では李らによるシステム ダイナミクス手法を用いた都市 $\mathrm{CO}_{2}$ 排出量の長期予測の研究があ る5)が、これも多種の統計資料から各産業や家庭に関する統計值を 予測し $\mathrm{CO}_{2}$ 排出量を算出しており、政策と建築物の性能との因果関 係は組み込まれていない。一方、ボトムアップ型では政策が対象に 影響を与える過程を追うことが容易であるのが特徴である。ボトム アップ型の省エネ施策に関するこれまでの研究としては、奥嶋によ るクリーンエネルギー車両の普及促進についての研究 6)など、環境 型商品の普及等を検討した研究例 7)はあるが、建築物の省エネ施策 について扱ったものは少ない。平野らが既存住宅を対象に省エネ政 策評価を提唱した例はある 8 が、オフィスビルを対象としたもので はない。海外では、Xin(2019)らがビルオーナーと政府の関係をモデ ル化し、省エネ改修を進める施策について研究を行っているが 9)、 契約関係がより複雑な賃貸ビルを対象にした研究ではない。

以上のように、賃貸ビルのように省エネ化の責任の所在や受益者 の関係が複雑な建築物において、省エネ施策がどのように機能する かモデル化し、その効果を明らかにした研究した事例はみられない。

\section{2 研究目的}

そこで本研究では、賃貸ビルにおけるビルオーナーとテナントの 行動ロジックをモデル化し、ボトムアップ型のシミュレーションを 行うことで、省エネ施策がストック建築物にどのように影響を与え、 結果運用時のエネルギー消費量がどのように変化するのか検討を行 った。シミュレーションの方法としては、複数要素の意思決定をモ デル化するマルチエージェントシミュレーション（Multi Agent Simulation, 以下 MAS) を採用した。

本研究については数年前より継続的に研究を進めてきたが 10)11)、

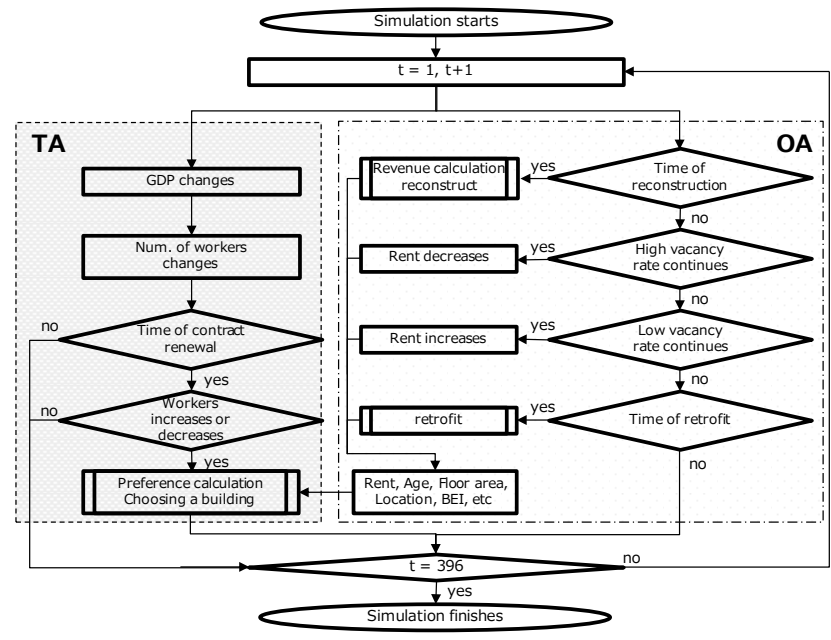

Fig.1 Flow chart of the model
仮想空間での非常に限られた規模（ビルオーナー数（ビル棟数）や テナント数）のシミュレーションであったため、現実の多様な条件 のビルを模擬するには至らず、施策の詳細な検討には限界があった。 ここでは、これまでの研究をベースにしながら、多様なビルの条件 を再現するような規模が大きいシミュレーションモデルを構築する ことで、より実態に即した施策検討を可能とした。なお、本論文は、 日本建築学会大会学術講演会にて発表したこれまでの研究内容 12 ) 15)に加筆・修正を加え再構成したものである。

\section{2. シミュレーションモデルの構築}

シミュレーションでは、ビルオーナーエージェント（以下 OA） とテナントエージェント（以下 TA）がそれぞれ、自身の利益が最大 となるように行動すると仮定した。つまり、MASにおいて、TAは 自身の効用を満たすようにオフィスビルに入居・退去し、OA は TA の行動を見てビルの性能や賃料を変化させていく、という行動ロジ ックに従うものとした(Fig.1)。現実のビルオーナー、テナントの行 動を忠実にモデル化するためには一つ一つの行動を非常に詳細に記 述する必要がある。しかし、本研究は大局的に OA、TAによって建 築物への投資がどのように変化するかを予測することが目的である。 そこで、変数やロジックは最小限必要なものにとどめ、最適化によ る調整や既往データからその確からしさを可能な限り高めることと した。実際にモデル化した行動ロジックの項目については、ビルの 運用段階のエネルギー消費に直接・あるいは間接的に関わると考え られるものを抽出し、運用と直接かかわりのない、ビルの取り壊し の際のフローや建て替えの際のエネルギー消費関連以外のビル性能 の決定フロー等については省略した。また、現実には TA が入居ビ ルの $\mathrm{OA}$ に直接設備機器更新を要求する場合も考えられるが、その 際の要求は多岐にわたり、モデル化することは難しいことから、本 研究では省略し TA の要求は入居・退居の行動により間接的に伝え られるものとした。

\section{1 オーナーエージェント（OA）の行動ロジック}

OA は、事務所ビルの収益にかかわる行動、またはエネルギー消 費量の増減にかかわる行動として、賃料変更、設備改修、建て替え を行うものとした。これら行動をモデル化した際の仮定と具体的な ロジックを記す。

\subsection{1 賃料変更}

建て替え、改修のない通常の運用時、一般に賃料増減の判断は空 室率をみて行うという既往のデータ 16 に基づき、自身のビルの空室 率 $21 \%$ 以上の状態が 6 ケ月続くと賃料を 231 円/坪下げ、空室率 $14 \%$ 以下が 6 ケ月以上連続した場合に 26 円/坪賃料上げることとした。

\section{1 .2 改修}

エネルギー消費の大きい主な建築設備の更新時期から 17)、OA は 20 年ごとに改修を行うこととした。省エネ改修によって削減される 一次エネルギー消費量は投資額によるものとし、その面積当たり初 期投資額 in と一次エネルギー消費削減量は既往研究 18)19) から Fig.2 のように決定した。inを 500 円 $/ \mathrm{m}^{2}$ 増額した際に増加する投資回収 年を、増額により期待される光熱費の削減額 $E B_{\text {in }}$ と賃貸収入増加額 $R I_{i n}$ から算出し、それが $P$ 年に収まる最大の in 初期投資額として 決定した(Fig.3)。EB in、RI $I_{i n}$ の算出に必要な値 $U_{i n} 、 R_{i n}$ は式(1),(2)の ように決定した。自分と条件の近いビルのなかで省エネルギー性能 
指標值（Building Energy-efficiency Index, BEI）の最も良いビルの 賃貸収入が自分より高かった場合、単位一次エネルギー消費削減量 当たりの賃貸収入増加見込み額 $R_{\text {unit }}$ が大きくなるとした(Fig.4)。 なお、大きな故障がない場合も建築設備は長期間の間に少しずつ劣 化が進むことから、各ビルの一次エネルギー消費量は 20 年の間に 約 1 割エネルギー消費量が増加するものとした ${ }^{20)}$ 。

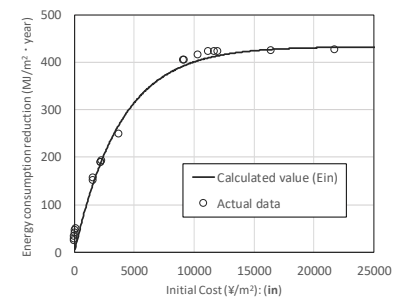

Fig.2 The relationship between reduction of energy consumption and initial cost

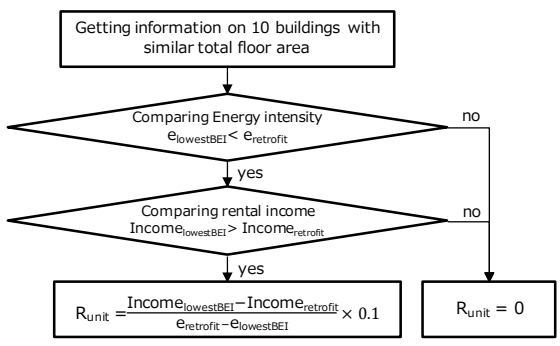

Fig.4 Estimation of $R_{\text {unit }}$

$U_{\text {in }}=\frac{p_{e}}{3.6} \times E_{\text {in }} \times$ Area $_{i}$

$R_{\text {in }}=R_{\text {unit }} \times E_{\text {in }} \times$ Area $_{i}$

$U_{\text {in }}$ : 初期投資額 in $の$ 時の光熱費削減額 $($ 円)

$p_{e}:$ 電気料金 $($ 円 $/ \mathrm{kWh})$

$E_{i n}$ : 初期投資額 in の時の一次エネルギー消費原単位削減量 $\left(\mathrm{MJ} / \mathrm{m}^{2}\right)$

$\mathrm{Area}_{i}$ : ビル $i$ の延べ床面積 $\left[\mathrm{m}^{2}\right]$

$R_{i n}$ : 初期投資額 in の時の賃貸収入増加見込み額(円)

$R_{\text {unit }}$ : 一次エネルギー消費削減量あたりの賃貸収入増加見込み額(円/MJ)

\section{1 .3 建て替え}

簡単のため、ビルは築 50 年を迎えると一律で建て替られるもの とした。建て替えの際には、延床面積や立地に関する情報は変更せ ず、BEI と初期賃料を再設定し、築年数を 0 年とした。BEI $の$ 再設 定には、BEI に応じた収益計算を行い、正味の予測収益が最大とな る BEI を選定した。

具体的には、ある BEI のビル $i$ について、その予測収益は建設費 用、運用費、予測賃貸収入によって決定されることとした（式(3))。

収益計算期間は、投資家がある性能の賃貸ビルに投資として想定 する期間の平均から ${ }^{21} 7$ 年とした。

また、既往文献 22)23)から一次エネルギー消費原単位と運用費、建 設費の関係を(式(4)、(5)) に基づいて算出した(Fig.5)。建設費は BEI が良いほど大きくなり、運用費は BEI が良い（小さい）ほど小さく なる。ここで、既往研究 ${ }^{244}$ による計算に基づき、BEI にかかる一次 エネルギー消費原単位 $e_{\text {ref }}$ と $\mathrm{OA}$ 機器の一次エネルギー消費原単位
$e_{O A}$ を式(6)のように設定した。電気料金は電力会社の法人向け電力 料金 ${ }^{25)}$ から $15[$ 円 $/ \mathrm{kWh}]$ とした。

建て替えたビルの初期賃料は、建て替え時点における他ビル群の 賃料をある幅をもった BEI 帯で分類し、本ビルの BEI が含まれる BEI 帯の平均賃料とした。予測賃貸収入はこの初期賃料に、その BEI 帯の平均専有率を乗じて単位面積当たりの賃貸収入を算出し、これ に延床面積を乗じて算出した（式(7)）。



注 1)式(3)のエネルギー消費原単位の減少量を 3.6 で除しているのは MJ か ら kWh への換算である。

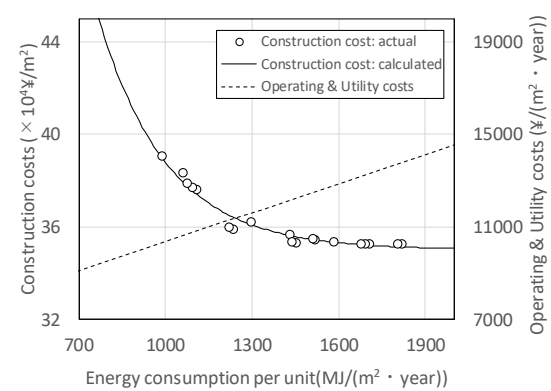

Fig.5 Relationship between construction costs, operation costs and energy consumption per unit

\section{2 テナントエージェント（TA）の行動ロジック}

テナントの主要な移転理由の一つに人員の増加・減少があること から 26)、 $\mathrm{TA}$ は契約更新時期(2 年毎)にオフィスワーカーが $2 \%$ 以上 増加または減少していた場合、新しいオフィスに移転するものとし た。現実には移転の理由は多様であるが、移転理由を代表するもの としてオフィスワーカー $2 \%$ の増減が移転の基準とした。移転すると 決定した場合、TA は離散選択モデルの一つである多項ロジットモ デルに基づき新しいオフィスビルを選択するものとした。テナント の各オフィスビルの選択確率は、各オフィスビルを選んだ場合の効 用の大小により決定される。ビル $i$ の選択確率 $p_{i}$ は各ビルの効用 $v_{i}$ か ら決定され(式(8))、効用 $V_{i}$ は各 $\mathrm{OA}$ の変数によって決定される(式 (9))。テナントがオフィス選択の際重視する項目に関する調査 ${ }^{25)}$ に よると、賃料、面積、最寄り駅の近さ、通勤の便等が重視されるこ とから、これらに関連するビル変数をテナントのオフィス選択の際 
の変数とした。さらに、そのほかのオフィス選択で重視する項目の うち、個別データが収集可能な築年数を変数に加え、さらに街のイ メージ・ブランドを表現可能な変数として、地区特性 $1 、 2$ (中央区 の地区計画に定められている高度利用地区に対応 $\left.{ }^{27}\right)$ ）という変数を 与えた。なお、オフィスワーカーの人数はランダム性を持ちつつ都 内総生産 $(\mathrm{GDP}(\mathrm{Tokyo}))$ に比例する傾向を持つとした(式(10))。 GDP(Tokyo)は周期的に変化する傾向があることからモデル式を三 角関数として近似した(fig.6)。

式(9)の効用の重みづけパラメータ $\alpha$ HA が何を重視するかという 重みづけであるが、既往文献等からは得られなかった。そこで、テ ナントが重視する項目はオフィスビルの賃料の上昇という形で反映 されると仮定し、現実のオフィスビル 100 棟の個別賃料 24)を評価基 準としてシミュレーション上での個別賃料がこれを再現できるよう に重みづけパラメータ $\alpha$ いいて最適化計算を行った。最適化計算 には遺伝的アルゴリズムを用い、2001年 12 月から 2018 年 6 月ま でを計算期間とした。2018 年 6 月時点での個別賃料の実績值と計 算值を用いて最小二乗法で評価し、その総和が最も小さくなるよう に最適化を行った。なお、 $\alpha_{B E I}$ については現状の効用は非常に小さ いとしてパラメータ $\alpha$ の調節時には 0 とした。

調節されたパラメータを Table 1 に示す。これらパラメータを用 いて計算した個別賃料と賃料実績值の相関係数は 0.69 となり、大局 的な傾向を観察する MAS においては比較的よく実績值を再現でき ているといえる(Fig.7)。

$$
\begin{aligned}
& p_{i}=\frac{\exp \left(v_{i}\right)}{\sum_{j} \exp \left(v_{j}\right)} \\
& v_{i}=\alpha_{0}+\alpha_{\text {Rent }} \text { Rent }_{i}+\alpha_{\text {Area }} \text { Area }_{i}+\alpha_{\text {Age }} \text { Age } e_{i} \\
& +\alpha_{\text {Passenger Passenger }}+\alpha_{\text {Distrct } 1} \text { District } 1 \\
& +\alpha_{\text {District } 2} \text { District } 2_{i}+\alpha_{B E I} B E I_{i}
\end{aligned}
$$

Rent: 賃料 Area: 延床面積 Age: 築年数 Passenger: 半径 $750 \mathrm{~m}$ 以内にある駅の乗客数 District1：地区特性 1 District2: 地区特性 2

$O W_{t}=O W_{t-1} \frac{G D P_{t}}{G D P_{t-1}} \times r$

$O W_{t}: \mathrm{t}$ 年のオフィスワーカー数(人)

$G D P_{t}: \mathrm{t}$ 年の $\mathrm{GDP}($ 円)

$\mathrm{r}$ : 平均 1 , 標準偏差 $15 \times\left|1-\frac{G D P_{t-1}}{G D P_{t}}\right|$ の正規分布からなる乱数、ただし 0 未満の場合 0 注 2)式(9)の地区特性 1 は立地が銀座地区、地区特性 2 は日本橋地区の場合 のダミー変数である。

注 3)GDP のモデル式における $\mathrm{x}$ は 2001 年 1 月を 1 とし月単位で 1 ずつ増え るものとしている。

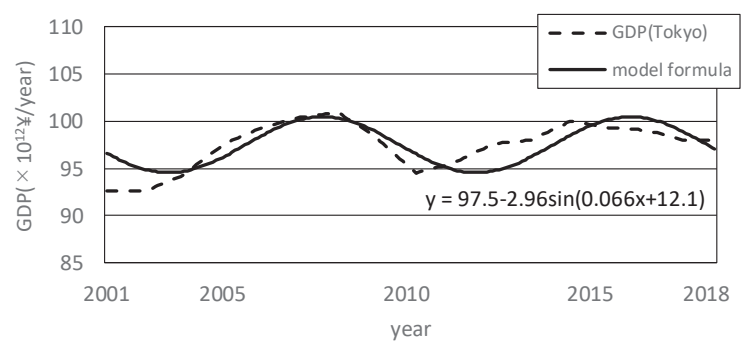

Fig.6 GDP(Tokyo) and model formula of GDP

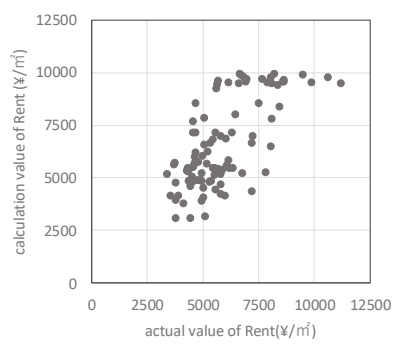

Fig.7 Actual and calculated value of rent

Table 1 The utility parameters

\begin{tabular}{ccccccc}
\hline$\alpha_{0}$ & $\alpha_{\text {Rent }}$ & $\alpha_{\text {Area }}$ & $\alpha_{\text {Age }}$ & $\alpha_{\text {Passenger }}$ & $\alpha_{\text {District1 }}$ & $\alpha_{\text {District2 }}$ \\
\hline 2.34 & -0.77 & 0.74 & -0.39 & 0.47 & 0.42 & 0.44 \\
\hline
\end{tabular}

\section{3 初期条件}

中央区の地理的情報を持つビル 1,000 棟(OA 1 個/棟)とそれに対応 した TA 10,233 のエージェントを設定した ${ }^{28)}$ (Table 2, Fig.8)。中央 区は東京都の中でもオフィス街の集まる地域の一つであり、中央区 のオフィス系ビル(複合ビル除く)が約 3,500 棟あることから、これ は東京都のオフィス街の特徴を十分再現し、オフィスビルのもつ多 様な条件を模擬するに足る規模だとみなした。築年数とエネルギー 性能は個別の情報がないため統計的に現実の值を模擬するように設 定した ${ }^{29)}$ 30)。参考まで、2.2. で設定したパラメータを用いて中央区 で 2001 年から現在までシミュレーションを行った時の計算終了時 のエリア毎の賃料分布を示す(Fig.9)。以上のように構築したモデル を用いて施策の効果予測を行った。計算期間は 2019 年から 2050 年 までの 32 年間、計算間隔は 1 ケ月とし、本シミュレーションに含 まれるランダム性により誤差が生じるリスクを抑えるため、一つの シナリオにつき 30 回繰り返し計算を行った。

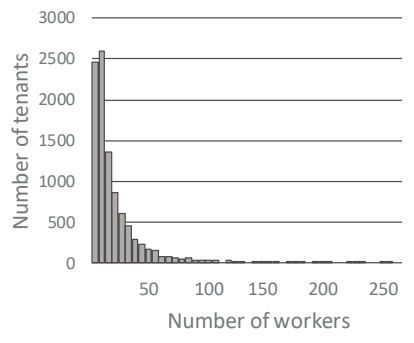

Fig. 8 Histogram of workers in a tenant

\begin{tabular}{|c|c|c|c|}
\hline & Max & Min & Average \\
\hline Total floor area $\left(\mathrm{m}^{2}\right)$ & 160915 & 1002 & 4834 \\
\hline Age (year) & 64 & 1 & 30.3 \\
\hline $\begin{array}{l}\text { Users of stations near the } \\
\text { building (/day) }\end{array}$ & 978650 & 0 & 378844 \\
\hline $\begin{array}{l}\text { Energy consumption per unit } \\
\left(\mathrm{MJ} /\left(\text { year } \cdot \mathrm{m}^{2}\right)\right)\end{array}$ & 5010 & 550 & 1533 \\
\hline Located in Ginza district & & $17.0 \%$ & \\
\hline Located in Nihonbashi district & & $15.5 \%$ & \\
\hline
\end{tabular}

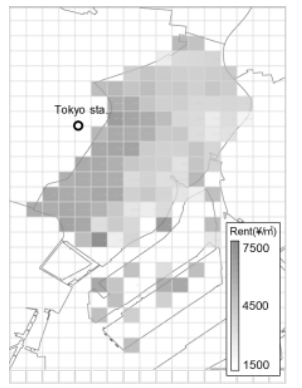

Fig.9 Rent distribution map
Table 2 Initial data of office buildings 


\section{3. 省エネ化施策}

省エネ基準順守義務、新築に対する補助金、改修に対する補助金 の 3 種類の施策の効果予測を行った。

\section{1 省エネ基準順守義務}

建築物省エネ法に含まれる省エネ基準順守義務は、一定面積以上 の新築建築物が省エネ基準を超えることを禁止するものである ${ }^{2)}$ 省エネ基準順守義務を施行する目的は、特に省エネ性能の良くない 建築物の新築を禁止することで、省エネ性能の底上げを図ることで あり、現在の基準 BEI は 1.0 である。現在、規制の対象となる延床 面積は $300 \mathrm{~m}^{2}$ 以上であり、本研究では全てのビルの延床面積がこれ より大きいため、全てのビルに省エネ基準順守義務が適用されると した。シミュレーション上においては、建て替えの収益計算の際に 省エネ基準を超える BEI のビルには建替えられないものとした。検 討パターンは、BEI=1.0 から 0.1 毎に 0.6 までの 5 通りとした。

\section{2 新築補助金}

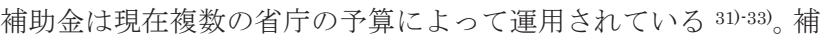
助金の利用により、省エネ化に係るイニシャルコストを軽減するこ とができる。省エネ設備導入を妨げる原因の一つが初期費用の高さ であるため、補助金で多くの建築物の省エネ化が進むと考えられる。 現在、新築建築物に対する補助金はZEB Ready (創エネ分を含ま ず $\mathrm{BEI} \leqq 0.5) の$ 達成を条件にしている場合が多い。そこで本研究で も $\mathrm{BEI} \leqq 0.5$ を新築補助金付与の条件とした。建て替えの収益計算 の際に BEI $\leqq 0.5$ ならば補助金による利益が追加される(式(11))。各 BEI としたことにより増加するイニシャルコストの、BEI $=1.0$ と 比較した増分に対して付与割合 Snew をかけた額が支給される。

補助金を利用寸れば $\mathrm{BEI} \leqq 0.5$ に建て替えられる OA を対象に、 一次エネルギー消費削減量を補助金付与額で除した值が大きい順に、 つまり一次エネルギー削減効率の良い順に補助金を付与し、付与し た補助金が総額の上限に達するか、全ての OA に付与するとその年 の補助金を終了することとした。

検討パターンとしては、補助金総額と、一棟当たりの付与割合を 変更した。補助金総額は年あたり 1.5 億円、 3 億円、 4.5 億円、 6 億 円、無制限の場合の 5 通り、付与割合は $1 / 6$ から $5 / 6$ までの 5 通り とした。なお、現実の新築、改修を合わせた補助金予算が非住宅建 築物に均等に振り分けられていると仮定して本シミュレーションの 総床面積に換算すると、約 3 億円/年となる ${ }^{31)-33) 。 ~}$

$$
\begin{aligned}
N B_{i, B E I}=-I C_{i, B E I}+\left(B_{i, B E I}-\right. & \left.R C_{i, B E I}\right) \times P_{p a y} \\
& +s_{\text {new }}\left(I C_{i, B E I}-I C_{i, 1.0}\right)
\end{aligned}
$$

\section{3 改修補助金}

改修補助金も新築補助金と同様にイニシャルコストを低減するこ とで省エネ改修を促進する。2.1.2 における初期投資額 in のうちの 一定割合 $S_{\text {ret }}$ を補助金が負担する。つまり、初期投資のうち OA が 負担する割合は $1-S_{\text {ret }}$ となるため、Fig. 3 で投資回収年 $P$ で回収可 能かどうかを判断する不等式が式(12)のようになる。ただし、現実 の改修補助金の例から、改修に対してはBEI の達成条件は設けず省 エネ改修の効率の良い順に補助金を付与寸ることとした。新築補助 金と同様に、シミュレーションでは補助金総額と一棟当たりの付与 割合を変更してその効果を検討した。検討パターンは新築補助金と 同様である。

$$
\frac{500 \times\left(1-s_{r e t}\right)}{R I_{\text {in }}+E B_{\text {in }}}>P
$$

以上のように設定した各施策の効果を次章以降でシミュレーショ

\begin{tabular}{|c|c|c|c|c|c|c|}
\hline Standard line & BEI & 1.0 & 0.9 & 0.8 & 0.7 & 0.6 \\
\hline \multirow{2}{*}{$\begin{array}{ll}\text { Subsidy } & \text { for } \\
\text { new }\end{array}$} & Subsidy rate & $1 / 6$ & $2 / 6$ & $3 / 6$ & $4 / 6$ & $5 / 6$ \\
\hline & $\begin{array}{l}\text { Total amount } \\
\times 10^{8} ¥ / \text { year }\end{array}$ & 1.5 & 3.0 & 4.5 & 6.0 & $\begin{array}{c}\text { No } \\
\text { limit }\end{array}$ \\
\hline \multirow{2}{*}{$\begin{array}{l}\text { Subsidy } \\
\text { retrofit }\end{array}$} & Subsidy rate & $1 / 6$ & $2 / 6$ & $3 / 6$ & $4 / 6$ & $5 / 6$ \\
\hline & $\begin{array}{l}\text { Total amount } \\
\times 10^{8} ¥ / \text { year }\end{array}$ & 1.5 & 3.0 & 4.5 & 6.0 & $\begin{array}{c}\text { No } \\
\text { limit }\end{array}$ \\
\hline
\end{tabular}
ンによって予測した。検討したパターンは Table 3 の通りである。

Table 3 Simulated policy pattern

\section{4. 効果予測}

各施策それぞれについて効果予測を行った結果を示す。

\section{1 省エネ基準順守義務}

Fig.10より、基準 BEI が厳しくなるほじ、一次エネルギー消費量 は減少していることがわかる。また、Fig.13、Fig.16から、基準が 厳しくなるほど BEI の分布する範囲は小さくなり基準 BEI 付近に ビルが集中していた。基準の厳格化により省エネ基準順守義務に期 待されるとおりの省エネ性能が底上げされることが確認された。

\section{2 新築補助金}

Fig. 11 は補助金付与率が $5 / 6$ の時の時系列の一次エネルギー消費 量、Fig.14、Fig17 がそれぞれ 2030 年、2050 年の付与率、総額別 平均 BEI である。いずれのグラフからも読み取れる通り、新築補助 金は付与総額を無制限とした場合にのみ、大きな効果を見込むこと ができ、総額が少ない場合大きな効果は認められない結果となった。 当然ではあるが、総額無制限の場合は付与率が大きいほど大きな一 次エネルギー消費量削減効果が見込まれた。総額 4.5 億、6.0 億円/ 年の場合は付与率 $4 / 6$ の場合に最も効果が大きかった。新築補助金 の特徵として、総額に制限有りの場合ほとんどの補助金が小規模ビ ルに付与されていた。一次エネルギー消費量の削減量については大 規模ビルの影響がより大きくなるため、平均 BEI では効果の確認で きる補助金総額 4.5 億、 6.0 億円/年の場合も一次エネルギー消費量 としては大きな効果を確認できなかった。Fig.19の通り、付与総額 上限なしの場合の年平均の補助金付与総額は約 40 億円であり、上 限ありの場合の 10 倍以上となっていた。そのため今回検討した上 限ありの補助金総額は一次エネルギー削減の観点からは不十分だっ たと判断できる。新築建築物はイニシャルコストが非常に大きく一 棟当たりの補助金付与額も大きくなるため、全体に補助金をいきわ たるようにするにはその総額は多額となると考えられる。今後技術 開発が進み、新築建築物の省エネ化にかかるイニシャルコストが低 減するまでは新築補助金は技術開発やその実証としての側面が強く なるものと予想される。

\section{3 改修補助金}

改修に対する補助金について、補助率 $2 / 3$ の場合の時系列の一次 エネルギー消費量の推移が Fig.12、2030 年、2050 年の平均 BEI が それぞれ Fig.15、Fig.18 である。Fig.12 から、2030 年ごろまでは 補助金総額が大きくなるほど省エネ化が進んでいることが認められ るが、その後は一次エネルギー消費量の減少があまり進んでいない 
ことがわかる。これは、補助金を受けて省エネ改修を行ったビルが その後 10 年で建て替えを行い、省エネ改修の効果がリセットされ てしまうことが理由として考えられる。特に、建替えを築 50 年で 行うとしている本モデルの場合、バブル期に建てられた多くのビル が 2035 年ごろから建替え時期を迎えることとなり (Fig.20)、それま での省エネ改修の効果が小さくなる。このことから、省エネ改修に 補助金を付与する場合は、短期的にどれだけ省エネ化するかだけで なく、その建物が何年残り続けるか、という長期的な視点も重要で あることがわかる。一方、効果が顕在化する 2030 年の平均 BEI を 見ると(Fig.14)、年総額 3 億円程度でも多少の効果が認められる。 この時補助率 $1 / 2$ で最も省エネ化が進んでおり、総額が大きくなる と最も効果のある補助率は大きくなる。新築と異なり改修への補助 金は一棟当たり必要額が小さいため、総額上限があっても補助率を 下げることで多くのビルに補助金がいきわたり、省エネ化が進んだ。 一方、総額が増えても上限のある場合とあまり差がないことから、 改修だけで省エネを進めるには限界があることもわかる。

早期に効果が得られることから、当面は改修補助金で省エネ化を 進めつつ新築補助金で技術開発を進める、というように役割を組み 合わせて行くことが重要ではないかと考えられる。築年数を踏まえ た新築・改修補助金の分配は最適化の余地があると考えられる。



Fig.10 Standard BEl:

Energy consumption from 2020 to 2050

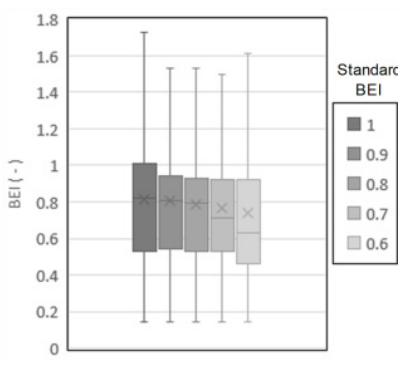

Fig.13 Standard BEI: Box plot of BEl in 2030

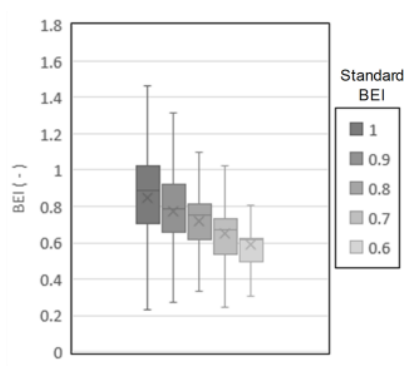

Fig.16 Standard BEI: Box plot of BEl in 2050

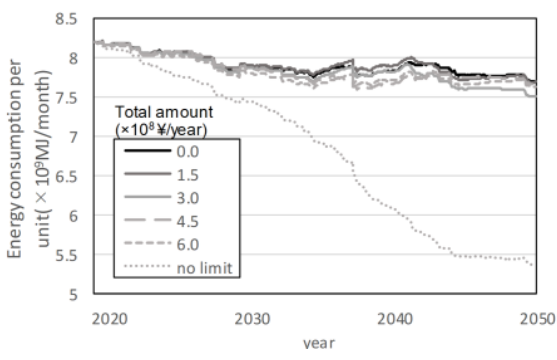

Fig.11 Subsidy for new built: Energy consumption from 2020 to 2050

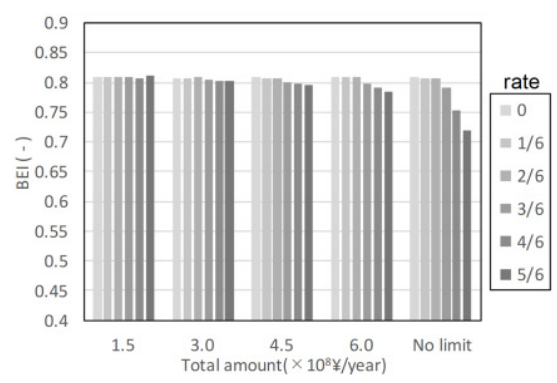

Fig.14 Subsidy for new built: Average BEI in 2030

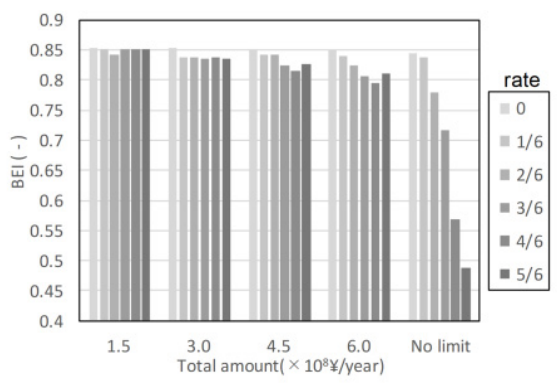

Fig.17 Subsidy for new built: Average BEl in 2050

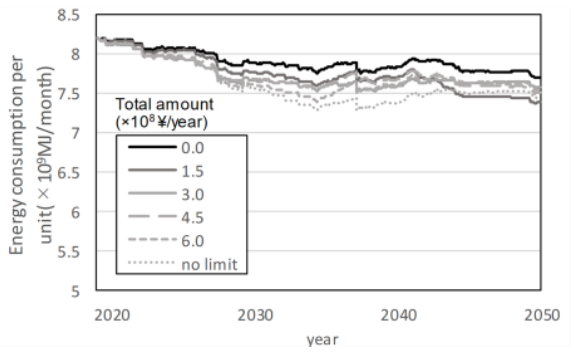

Fig.12 Subsidy for renovation Energy consumption from 2020 to 2050



Fig.15 Subsidy for renovation Average BEl in 2030

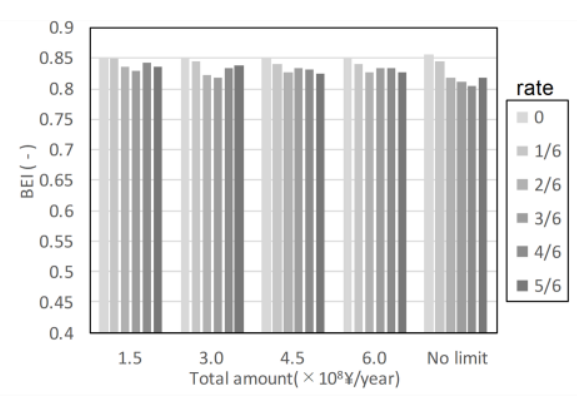

Fig.18 Subsidy for renovation Average BEI in 2050 


\section{5. テナントの省エネ志向が高まった場合の検討}

前述の施策はいずれもオーナー側に働きかけるものであるが、テ ナント側の省エネ志向が高まった時に省エネ化がどのように進行す るかを検証した。式(9)において BEI に対する効用パラメータ $\alpha_{B E I}$ の 值を変更することで TA の省エネ志向が変化する。 $\mathrm{BEI}$ は小さい方 が良い性能であるため、省エネ志向が高いとき $\alpha_{B E I}$ は負の值となる。 $\alpha_{B E I}$ は-0.1,-0.2,-0.3,-0.4の 4 通りを検討した。多項ロジットモデル においてパラメータにかかる係数による効果を絶対的に評価するこ とは難しいが、他のパラメータとの大小比較は可能である。 $\alpha_{B E I}=$ 0.4 の時にはTable1 から築年数や地区による影響とほぼ同じ重要度 を持ち、 $\alpha_{B E I} \geqq-0.3$ の時にはより小さい影響を持つといえる。

\section{1 単体の効果予測}

施策が適用されていない場合に $\alpha_{B E I}$ が変化したときの一次エネル ギー消費量の時系列グラフが Fig.21である。最終的には効果が大き い一方、2035 年ごろまではあまり効果が現れず、それ以降に一気に 省エネ化が進んでいることがわかる。テナントの省エネ志向が高く なった場合、(1) TA が BEI の良いビルを選好するようになる、(2)BEI の良いビルの空室率が下がり賃料が上がる(Fig.22)、(3)OA が BEI の良いビルに建て替え、改修を行いやすくなる、という 3 つのス ップで省エネ化が進行するため、効果が現れるまでに時間がかかる と考えられる。

現実ではテナントの要求はオフィス選択だけでなく直接的な要望 としてもオーナーに伝わるためもっと早く省エネ化は進むと考えら れるが、いずれにしてもテナント側の省エネ化の要求が高まっても 反映されるまでにいくらかの時間がかかることに注意が必要である。 2050 年の BEI の箱ひげ図である Fig. 23 を見ると、 $\alpha_{B E I}$ が小さくな ると最終的な BEI は改善されている。分布の特徵として BEI が低
い值から高い值まで幅広く分布していることが Fig.16 と比較する とわかる。つまりテナントの省エネ志向の向上は、BEI の底上げは できないものの、BEI のより良いビルを増やす効果があるといえる。

\section{2 各施策との組み合わせ検討}

Fig.23のように、義務基準 BEI が厳しくなった時、 $\alpha_{B E I}$ が小さく なったことによる効果は小さくなる。この結果は基準順守義務とテ ナントの省エネ志向の向上どちらも単独で十分な省エネ化が可能で ある一方、両者の相乗効果は大きくないことが示唆している。

Fig.24 は $\alpha_{B E I}=-0.4$ で新築補助金ありの時の 2050 年平均 BEI である。新築補助金のみの場合の Fig.17 と比較すると、総額がより 小さい值の時も補助金による省エネ化が進んでいることがわかり、 総補助額 3 億円/年以上の時平均 BEI が改善している。特に Fig.17 では 4/6 5/6 などの大きな補助率が有効だったのに対して、Fig. 24 では補助率 $2 / 6$ という小さい補助率で最も平均 BEI が改善している 点が特徴的である。 $\alpha_{B E I}$ の影響が強まると、省エネビルに建て替え たときの賃貸収入増加が見込めるため、一棟当たりの補助率が小さ くても多くのビルが補助金を利用して BEI $=0.5$ 以下に建替えられ ること、結果限られた補助金総額で多くのビルに補助金を付与でき、 平均 BEI が改善することがわかる。このことから、省エネ基準遵守 義務との組み合わせとは対照的に、テナントの省エネ志向が高まる ことと新築に対する補助金は正の相乗効果があることを示唆する。

Fig.25, Fig.26は $\alpha_{B E I}$ が強まった場合で改修補助金が年 6 億円の 時の一次エネルギー消費量の変化である。改修補助金のみが適用さ れていた Fig.12 と比較するとわかるように、 $\alpha_{B E I}$ が小さくなると 2035 年以降も継続的に一次エネルギー消費量が減少していく。前述 の通り早期に効果が得られるもののその効果が持続しにくい改修補 助金と、効果が現れるまでに時間のかかるテナントの省エネ志向の

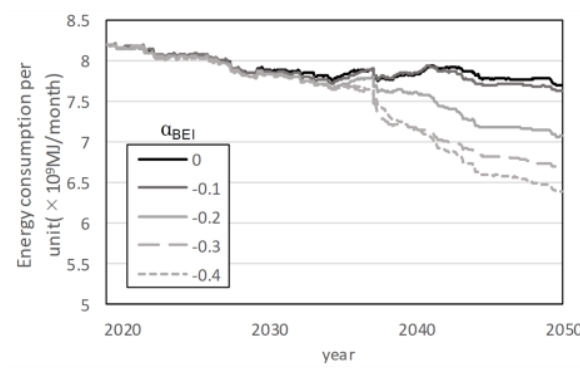

Fig.21 $\alpha_{B E I}$ :

Energy consumption from 2020 to 2050

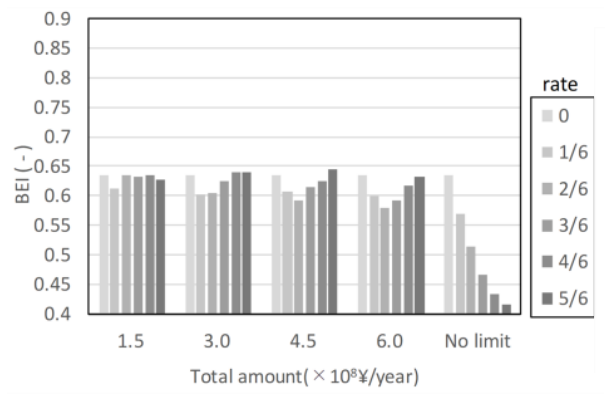

Fig.24 $\alpha_{B E I}=-0.4$, subsidy for new built: Average $\mathrm{BEI}$ in 2050

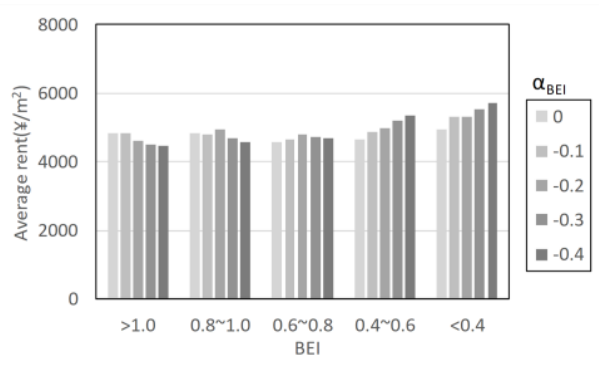

Fig.22 $\alpha_{B E I}$ :

Average rent divided by BEI in 2050

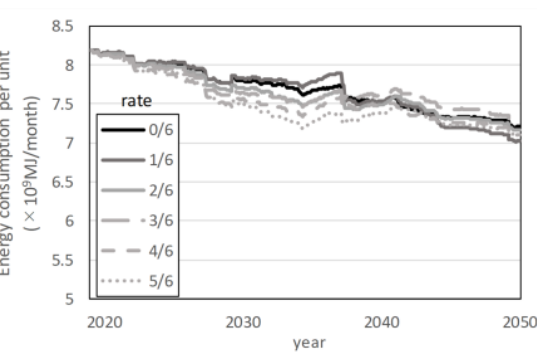

Fig.25 $\alpha_{B E I}=-0.2$, subsidy for retrofit: Energy consumption from 2020 to 2050

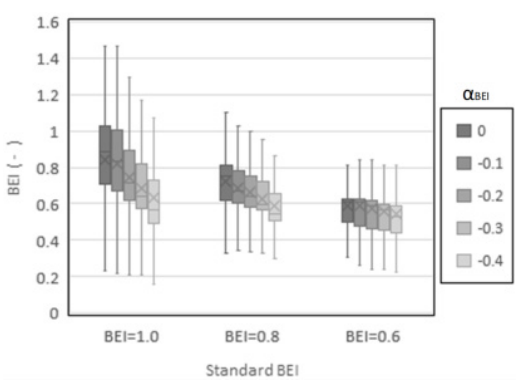

Fig.23 standard $\mathrm{BEI}$ and $\alpha_{B E I}$ : Box plot of BEl in 2050

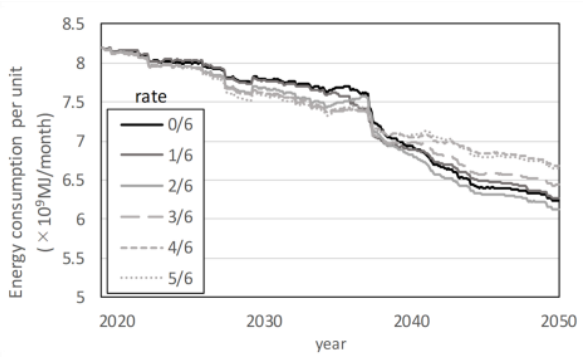

Fig.26 $\alpha_{B E I}=-0.4$, subsidy for retrofit: Energy consumption from 2020 to 2050 
向上は、適切に組み合わせれば継続的に省エネ化を進めることがで きる可能性がある。

ただし、Fig.26の 2050 年時点の值をみると、補助率が高い方が 補助率 0 の場合より一次エネルギー消費量が大きい場合がある。こ の理由として、補助金が一次エネルギー削減効率の良い順に付与さ れることから、BEI の大きい(良くない)ビルに行き渡りやすくなっ ていることが考えられる。 $\alpha_{B E I}$ が強まっている場合、BEI の良くな いビルは貨料が下がった状態で補助金を受け取り省エネ改修するこ とになるため、省エネ化した後の BEI 帯の平均賃料に悪影響を与 え、全体として省エネ化が進みづらくなる現象がみられた。この部 分については、現実の挙動とやや異なると考えられるため、今後改 善していく必要がある。

\section{6. 結論}

テナントとビルオーナーの行動をモデル化した MAS を用いて建 築物の省エネ施策効果の予測と、テナントが省エネビルを志向する ようになった場合のエネルギー消費量の変化について検討した。新 築補助金により大きな効果を得るにはその総額は大きくなること、 改修補助金により早期的な効果が得られるものの長期的には効果が 収束してしまうことなどが示唆された。また、テナントの省エネ志 向が高まると、最終的にエネルギー消費量を大きく減らせるものの 効果が現れるには時間がかかること、義務基準との組み合わせはあ まり効果的でないが新築補助金とは相乗効果があり、改修補助金と 適切に組み合わせると継続的に省エネ化が進む可能性があることな どを明らかにした。今後の課題として、テナントがビル選択の際に 省エネ志向を持つようになるための具体的な施策・方法を検討する ことなどが考えられる。

本シミュレーションは限られた情報で構築され仮定・単純化を含 むことからその予測精度には課題が残る。しかし、MAS という手法 で社会構造をボトムアップ方式でモデル化し、ステークホルダーの 行動の変化からエネルギー消費の動向を予測するというシミュレー ション手法は、様々な要素がどのように相互作用しあって社会を変 化させていくのかを解き明かす示唆を得られるという点で、非常に 有用である。また、エージェントの種類と行動原理を追加すること で、新たな政策や今日のコロナによる行動制限のような社会情勢の 変化等を考慮する場合にも応用可能だと考えられる。これらの点で、 本研究は今後の建築物の省エネ施策に関する研究に資するものであ ると考えられる。

\section{参考文献}

1) Global Warming Prevention Headquarters: Submission of Japan's Intended Nationally Determined Contribution, 2015 地球温暖化対策推進本部：日本の約束法案, 2015

2) The act on the Improvement of Energy Consumption of performance of buildings, 2015

建築物のエネルギー消費性能の向上に関する法律, 2015

3) Iba Hitoshi: Agent-Based Modeling and Simulation with Swarm, CRC Press, 2013

4) Ikaga T. et. al.: Estimation of $\mathrm{CO}_{2}$ Emission Associated with Building Construction and Operation till 2050 in Japan, Journal of Architecture and Planning (Transactions of AIJ), Vol.65, No.535, pp. 53-58, 2000. 9 (Japanese)
伊香賀俊治他: 我が国の建築関連 $\mathrm{CO}_{2}$ 排出量の 2050 年までの予測一建築・ 都市の環境負荷評価に関寸る研究一, 日本建築学会計画系論文集, 65 巻, 第 535 号, pp. 53-58, 2000. 9

5) Lee J. et. al.: Long-term Prediction of Effects that Spreading Solar Power System Reduces $\mathrm{CO}_{2}$ Emission in House Sector, Proceeding of the Architectural Research Meetings, Kanto Chapter, Architectural Institute of Japan II, Vol. 86, pp. 281-284, 2016 (Japanese) 李知殷他 : 家庭部門の太陽光発電システム普及による都市 $\mathrm{CO}_{2}$ 排出削減効 果の長期予測, 2015 年度日本建築学会関東支部研究報告集 II, 86 巻, pp. 281-284, 2016

6) Okushima M.: Multi-Agent Simulation for Promoting Clean Energy Vehicle with Economical Measure, Journal of Japan Society for Fuzzy Theory and Intelligent Informatics, Vol 28, No.5 pp. 846-854, 2016 (Japanese)

奥嶋政嗣 : クリーンエネルギー車両普及促進に関するマルチェージェント シミュレーション, 知能と情報(日本知能情報ファジィ学会誌), Vol.28, No.5, pp. 846-854, 2016

7) Hosoi M.: Design and Development of Environmental Business Strategy Model through a Multi-agent Simulation, Journal of Osaka University of Economics, Vol. 66, No. 1, pp. 327-341, 2015 (Japanese) 細井真人：マルチェージェントシミュレーションによる企業の環境戦略モ デルの構築, 大阪経大論集, 第 66 巻第 1 号, pp. 327-341, 2015

8) Hirano T. et. al.: Study on policy design for energy saving of existing houses: development of policy evaluation simulator using MAS, Proceeding of the Architectural Research Meetings, Kanto Chapter, Architectural Institute of Japan, Vol. 75, pp. 329-332, 2005.2 (Japanese) 平野智子他：既存住宅の省エネ化を目指した政策デザインに関する研究: MAS を用いた政策評価シミュレータの開発, 日本建築学会関東支部研究 報告集, Vol. 75, pp. 329-332, 2005.2

9) Xin Liang et. al.: Making incentive policies more effective: An agentbased model for energy-efficiency retrofit in China, Energy Policy, Vol. 126, pp. 177-189, 2019

10) Masuda T.: Process of Making Decisions of Building Owner and Tenants in Office Building and Prediction of Energy Policies' Effect, Thesis for Master Degree, School of Engineering, Department of Architecture, the University of Tokyo, 2018 (Japanese)

益田太平 : オフィスビルにおけるテナント・オーナーの意思決定と省エネ 施策効果の予測, 東京大学建築学専攻修士論文, 2018

11) Hasada H.: Effect and Spread of Retrofit for Energy-saving in Office Building by Green Lease Contract: Thesis for Bachelor Degree, School of Engineering, Department of Architecture, the University of Tokyo, 2019 (Japanese)

羽佐田紘之：グリーンリース契約によるビル省エネ改修の普及と効果，東 京大学工学部建築学科卒業論文, 2019

12) Oto Y. et. al.: Decision Making of Tenants/Owners and Prediction of Effectiveness of Energy Saving Measures in Office Buildings (Part 1) Outline of Prediction Method Using Multi Agent Simulation, Summaries of Technical Papers of Annual Meeting, Architectural Institute of Japan, Environmental Engineering-I, pp. 733-734, 2018.7 (Japanese) 大音裕紀他：オフィスビルにおけるテナント・オーナーの意思決定と省エ ネ施策効果の予測（その 1）マルチェージェントシミュレーションを用い た予測手法の概要, 日本建築学会大会学術講演梗概集, 環境工学 I ,pp. 733-734, 2018.7

13) Masuda T. et. al.: Decision Making of Tenants/Owners and Prediction of Effectiveness of Energy Saving Measures in Office Buildings (Part 2) Case Studies with Energy Conservation Standards, BELS and Subsidy, Summaries of Technical Papers of Annual Meeting, Architectural Institute of Japan, Environmental Engineering-I, pp. 735-736, 2018.7 (Japanese)

益田太平他 : オフィスビルにおけるテナント・オーナーの意思決定と省エ ネ施策効果の予測（その 2) 省エネ基準適合義務化、BELS 普及、補助金 交付によるケーススタディ, 日本建築学会大会学術講演梗概集, 環境工学 I , pp.735-736, 2018.7 
14) Hasada H.: Prediction of Energy Saving Policies in Office Buildings Using Multi-Agent Simulation (Part 1) Spread and Effect of Energy Saving Renovation Due to Green Lease Agreements, Summaries of Technical Papers of Annual Meeting, Architectural Institute of Japan, Environmental Engineering-I, pp. 937-938, 2019.7 (Japanese) 羽佐田紘之他：マルチェージェントシミュレーションを用いたオフィスビ ルにおける省エネ施策効果の予測（その 1) グリーンリース契約によるビ ル省エネ改修の普及と効果, 日本建築学会大会学術講演梗概集, 環境工学 I , pp. 937-938, 2019.7

15) Oto Y.: Prediction of Energy Saving Policies in Office Buildings Using Multi-Agent Simulation (Part 2) Setting of Outside Area and Case Study by Combination of Three Policies, Summaries of Technical Papers of Annual Meeting, Architectural Institute of Japan, Environmental Engineering-I, pp. 939-941, 2019.7 (Japanese)

大音裕紀他：マルチェージェントシミュレーションを用いたオフィスビル における省エネ施策効果の予測（その 2) 外部エリアの設定と 3 種類の施 策の組み合わせによるケーススタディ, 日本建築学会大会学術講演梗概集, 環境工学 I , pp. 939-941, 2019.7

16) Miki Shoji Co.: "Office Data",

https://www.e-miki.com/market/datacenter/index.html (accessed 2019.12.1)

三鬼商事 : ”オフィスデータ”（参照 2019.12.1）

17) Building and Equipment Long-life Cycle Association: Data for Life Cycle management of Building, revised $4^{\text {th }}$ edition, 2014

ロングライフビル推進協会 : 建築物のライフサイクルマネジメント用デー 夕集，改訂第 4 版, 2014

18) Ministry of Environment: "Cost Performance of Retrofit for Energysaving”, http://www.env.go.jp/earth/info/greenbuilding/about/cp.html

, (accessed 2020.01.15)

環境省 : ”省エネ改修の費用対効果” (参照 2020.01.15),

19) Suenaga N. et. al.: Applicability Evaluation Study of ZEB Technologies to Existing Buildings (Part 1) Building Stock Surveys and Study on Applicability of ZEB Technology to own Building, City and Environment, Air-conditioning and Sanitary Engineers of Japan, Vol.10, pp. 325-328, 2018 (Japanese)

末永直之ほか: 既存建築物に対する ZEB 化技術の適用性評価研究(第 1 報), 空気調和・衛生工学会大会学術講演論文集, 第 10 巻 都市・環境編, pp. $325-328,2018$

20) Ito S. et.al.: Continuous Energy Management of the HVAC \& R System in an Office Building Part4 Estimation of Energy and Cost Saving Effect, Air-conditioning and Sanitary Engineers of Japan, pp. 2225-2228, 2007 (Japanese)

伊藤祥一ほか: 事務所ビルの継続的な空調エネルギー管理に関する研究(第 4 報）省エネ・省コスト効果の推定, 空気調和・衛生工学会学術講演論文 集, pp. 2225-2228, 2007

21) Japan Real Estate Institute: $37^{\text {th }}$ Research of Real Estate Investor, 2017 (Japanese)

一般財団法人日本不動産研究所 : 第 37 回不動産投資家調査, 2017

22) Committee for Following up ZEB Road Map : Guideline of ZEB design (part middle-grade Office), 2018 (Japanese)

ZEB ロードマップフォローアップ委員会 : ZEB 設計ガイドライン(中規模 事務所編), 2018

23) The Association for Real Estate Securitization: ARES J-REIT Property Database, 2019 (Japanese)

一般社団法人不動産証券化協会： ARES J-REIT Property Database,2019

24) Lim J et. al.: Effects of Obligatory Energy Conservation and the Raise of Its Standards on Long-term Energy Consumption in Building Sector (Part 1) An Outline of a Long-Term Prediction Method of Energy Consumption in Office Building Stock, Summaries of Technical Papers of Annual Meeting, Architectural Institute of Japan, Environmental Engineering-I, pp. 789-790, 2017.7 (Japanese)

林鍾衍他 : 省エネ基準への適合義務化と義務基準引き上げが将来のエネル ギー消費量の変化に与える影響（その 1) オフィスビルに対するストック 全体の一次エネルギー消費量の将来予測手法の概要, 日本建築学会大会学 術講演梗概集，環境工学 I ， pp. 789-790, 2017.7
25) Tokyo Electric Power Company Holdings: "Power Plan", https://www.tepco.co.jp/jiyuuka/service-

corporate/kanto/power/index-j.html , (accessed 2020.4.8) (Japanese) 東京電力エナジーパートナー : "動カプラン”, (参照 2020.4.8)

26) Mori Building: a Research about office needs in 23 wards of Tokyo, 2017 (Japanese)

森ビル : 2017 年東京 23 区のオフィスニーズに関する調査, 2017

27) Chuo City: Change of District Plan, 2019(Japanese)

中央区 : 地区計画の変更について,2019

28) Zenrin: Building point data,2016

ゼンリン: 建物ポイントデータ, 2016

29) Xymax Real Estate Institute: an Office Pyramid in 23 wards of Tokyo 2019, 2019 (Japanese)

ザイマックス不動産総合研究所: 東京 23 区オフィスピラミッド 2019, 2019

30) Japan Sustainable Building Consortium: Data-base for Energy Consumption of Commercial buildings, 2019

日本サステナブル建築協会 : 非住宅建築物の環境関連公開データベース, 2019

31) Agency for Natural Resources and Energy: "Subsidy for Promoting Investigation for Saving Energy”, https://www.enecho.meti.go.jp/appli/ public_offer/1901/190125d/ pdf/4.pdf, (accessed 2020.1.12) (Japanese) 資源エネルギー庁：”省エネルギー投資促進に向けた支援補助金”，（参照 2020.1.12)

32) Ministry of Environment: "Decarbonization and Resilience Strengthening Promotion Project for Building”, http://www.env.go.jp/earth/earth/ondanka/energy-taisakutokubetsukaikeir02/matr02-01-20f.pdf, (Accessed 2020.1.12) (Japanese) 環境省：“建築物の脱炭素化・レジリエンス強化促進事業”, (参照 2020.1.12)

33) Ministry of Land, Infrastructure, Transport and Tourism: "Existing Building Energy Saving Promotion Project", http://www.mlit.go.jp/common/001285465. pdf , (Accessed 2020.1.12) (Japanese)

国土交通省：“既存建築物省エネ化推進事業” , 入手先（参照 2020.1.12） 


\author{
YukiOTO ${ }^{* 1}$, Yasunori AKASHI ${ }^{* 2}$,Jongyeon LIM ${ }^{* 3}$, \\ and Shohei MIYATA*4 \\ ${ }^{1}$ Obayashi Corporation (Former Grad. Student, Dept. of Architecture, Faculty of Engineering, The University of Tokyo), M.Eng. \\ ${ }^{2}$ Prof., Dept. of Architecture, Faculty of Engineering, The University of Tokyo, Dr.Eng. \\ ${ }^{3}$ Assist. Prof. / Ph.D., Dept. of Architectural Engineering, Kangwon National University. / \\ Assist. Prof. / Ph.D., Dept. of Integrated Energy and Infra System, Kangwon National University \\ ${ }^{4}$ Assist. Prof., Dept. of Architecture, Faculty of Engineering, The University of Tokyo, Dr.Eng.
}

Following the Paris Agreement adopted in 2015, Japan has set a goal of reducing greenhouse gas emissions by $26 \%$ from 2013 by 2030. In this context, the business sector is required to reduce greenhouse gas emissions by $40 \%$. The government has been promoting energy saving by some measures. Predicting the effects of each energy-saving policies will make it possible to consider a more effective combination of policies, and it will be useful for studying future policy making. In this study, we developed a simulation that modeled the behavior of tenants and building owners and we used the simulation to predict the effect of energy saving policies on buildings. We also examined changes in energy consumption when tenants prefer energy-efficient buildings. Chapter 2 explained a model in detail. This is a MultiAgent Simulation model that simulates the behavior of building owners and tenants, who are stakeholders of office buildings. One thousand building owners and about 10,000 tenants act in order to satisfy their own profits. In particular, building owners change their rent, reconstruct and renovate so that they can get more their lifecycle profits. If they think that energy-efficient building is profitable, they change their buildings to the green ones. On the other side, tenants often move to a new office in order to satisfy their utility. If tenants prefer the energy-efficient office, their intention affect the owners' decision making indirectly. Parameters of utility are estimated so that calculated rental value of buildings simulates the actual value. Using this simulation, we predicted the policy effects of energy saving in building sector from 2020 to 2050 in Chapter 4. The considered policy is "energy-efficiency standard compliance", "subsidy for new buildings" and "subsidy for renovation". As a result, we knew some important findings. For example, making energy-efficiency standard compliance severe is effective. It was also found that subsidies for new buildings require a large amount of subsidies to achieve an effect because building a new office requires a lot of money and little amount of subsidies cannot distribute properly to new buildings. Furthermore, we found that subsidies for renovation can be effective at an early stage, but the effects will not continue over the long term because renovated buildings are often reconstructed to the new buildings and the effects of subsidy will end at that time. In addition to those policies, we studied the scenario the tenant's intension increases to save energy consumption in Chapter 5. As a result, tenants' intension to energy-efficiency makes energy consumption greatly reduced in the end, but it takes time for the effect to appear. We also studied the combination between tenants' intention and the policies in Chapter 4 . The combination with the standard compliance is not very effective. Otherwise, there were the synergistic effect with subsidies for new buildings. It was also clarified that there is a possibility that energy conservation will continue to progress if properly combined with subsidies for renovation. As a future task, it is conceivable to consider specific measures for tenants to intend energy-saving when selecting a building. However, since this simulation is constructed with limited information and includes assumptions and simplifications, there remains a problem in its prediction accuracy. It is also necessary to consider a method for verifying the prediction accuracy while aiming for a more detailed model construction. 